\title{
Representatives and Senators
}

Reader, suppose you were an idiot. And suppose you were a member of Congress. But I repeat myself. (Mark Twain)

Once the November elections are over, the newly elected Representatives and Senators gather the following January for the start of the new Congress. Out of the thousands of hopefuls who started the arduous process of campaigning in the primary and general elections, only 535 people sit as members of Congress for the next two years; 435 in the House and 100 in the Senate. For most of those members, this will not be a new experience; only one-third of the Senate's seats are up for election at any one time (leaving two-thirds of the Senate to continue their six-year term without the need for re-election) and the majority of the other members of Congress will be returning to their offices after successful reelection. As discussed in the previous chapter, on average, over 90 per cent of the Representatives and Senators who choose to run for re-election are successfully returned to the next Congress. 


\section{What sort of person gets elected?}

To make an overgeneralisation, the typical person who wins election to Congress is a white male lawyer. It would appear, at first sight, that the second part of President Lincoln's famous proclamation at Gettysburgh of 'government of the people - by the people - for the people' has yet to be fulfilled. However, this is still a matter for debate. The 2000 elections ensured that the 107th Congress would contain an unprecedented number of women: 61 in the House of Representatives and 13 in the Senate. In addition, the 107th Congress benefited from 38 African American and 21 Hispanic members, all in the House. While this is an improvement on ten or twenty years ago, Congress is still some way from reflecting the wide and varied demographics of American society. While women, African Americans and Hispanics represent 51 per cent, 12 per cent and 12 per cent of the overall population respectively, they contribute 17 per cent, 9 per cent and 5 per cent of the members of the United States Congress. ${ }^{1}$

In terms of members' previous occupations, Congress is an institution dominated by lawyers and businessmen. In the 106th Congress (1999-2001), when asked to list their previous occupations, over 40 per cent of Senators and Representatives claimed to be lawyers. The next largest category, with 35 per cent, was business or banking, with politicians coming in third (Box 3.1). ${ }^{2}$ Several reasons can be suggested for this dominance by the legal and business communities. People from these occupations often benefit from their connections in the worlds of politics and business which are vital for building support and collecting campaign funds. They will often have already acquired the public speaking, negotiating and networking skills needed in the political arena, and, 
perhaps most importantly, they are given an advantage in having careers and salaries which allow them to take the time off to dedicate to an election campaign. It also may be that lawyers and businessmen are looked to and trusted to fulfil the role of member of Congress, quite simply because they resemble the majority of those who are already doing the job; in other words, they act and appear in the way people have come to expect their representatives to behave.

Box 3.1 Previous occupations of members of the 106th Congress (members may list more than one)

- 217 lawyers

- 184 businessmen/bankers

- 124 public service/ politicians

- 99 educators

- 28 farmers/ranchers

- 24 estate agents

- 17 journalists

- 17 medical professionals

- 10 law enforcement officers

- 9 engineers

- 5 miscellaneous fields

Source: Congressional Quarterly Weekly Report
- 3 professional athletes

- 3 skilled labor

- 3 healthcare providers

- 2 actors/entertainers

- 2 artists

- 2 clergy

- 2 military officers

- 1 aerospace professional

- 1 labour official

- 1 homemaker

- 1 secretary

Should this difference between the diversity of the American population and the relative homogeneity of the members of Congress be a cause for concern? Critics argue that true representation cannot be achieved while the nation's legislature is dominated by people from one section of society. However well-intentioned any member of Congress tries to be, they will never fully understand the position of different groups or individuals because they have never been through 
their situations or experiences. It is argued that this is not just a matter of how each representative casts their vote, but one of which issues or problems are seen as important enough to have a prominent place on the national agenda. In short, with Congress, the business world and the mainstream media dominated by wealthy white men, politics will inevitably have a wealthy white male agenda.

Alternatively, it can be argued that representation in a democracy does not require the legislature to be a reflection of society. How a member of Congress behaves, casts their votes and which issues they choose to prioritise is far more important than their gender, colour or class. If a representative is not fulfilling these roles to the satisfaction of the majority of their constituents, they will not be re-elected. Indeed, the Senator for somewhere like California has the job of representing voters from all possible communities and groups. It is not possible for a member to physically resemble all the people they represent. It is also claimed that it is a mistake to assume that on any one issue there is a distinct male, female, African American or Hispanic view; people from all sections of society have differing opinions on all issues, a fact which would not be changed by a more diverse Congress. Business and law are both professions where you are likely find some of the most well-educated and talented Americans, it is argued that it is to Congress' credit that it attracts the brightest individuals when careers other than politics are likely to pay better. Finally, it is contended that Congress is becoming more and more diverse, with the percentages of women and minorities represented rising steadily. Furthermore, while many lawyers are elected, the 107 th Congress (2001-2003) also included members with previous experience as, among others, a florist, a steelworker, a river- 
boat captain, a hotel bellhop, a taxicab driver and a racetrack blacksmith. ${ }^{3}$

\section{Members' goals}

On election night, once the votes have been counted, each successful candidate will make a victory speech to their supporters and, through the media, to their wider constituency. Most of these speeches follow the same pattern, the candidate will thank the voters for their support and acknowledge the work of their staff and volunteers, they will thank and extend a hand of friendship to their opponent and his or her supporters, promising to represent all the people of the district or state. They will touch on the key issues of the campaign, promising to concentrate their efforts to make a difference in these particular areas and finally they will pledge themselves to working as hard as they can in the interests of all constituents. On election night, these promises are easy to make; achieving them once in Congress is another matter entirely.

Whatever is said on election night, is it possible to make judgements on the priorities and goals of members of Congress? For the majority of members, their main priority is to be re-elected in two or six years time. In his influential text Congress: The Electoral Connection, David Mayhew paints a picture of members of Congress as 'single-minded seekers of re-election'. ${ }^{4}$ According to Mayhew, while in office, members engage in advertising, credit-claiming and position-taking in order to make a favourable impression on the voters back home; their decisions made with a constant eye on the reaction of their constituents. While he accepts that other motivations will exist in Congress, Mayhew argues that 
the electoral goal has an attractive universality to it. It has to be the proximate goal of everyone, the goal that must be achieved over and over if other ends are to be entertained. One former Congressman writes, 'All members of Congress have a primary interest in getting re-elected. Some members have no other interest'. Re-election underlies everything else, as indeed it should if we are to expect that the relation between politicians and public will be one of accountability. ${ }^{5}$

If this image of members of Congress dedicated solely to retaining their jobs at the next election is true, should it worry the American public? The quotation above suggests that it should not; that in a democracy it is the job of members of Congress to represent the wishes of their voters. The democratic principle of accountability means members would be failing in their role if they did not keep a constant watch on how their behaviour will be viewed by their constituents and modify their actions accordingly. However, Mayhew's study also raises some worrying questions about the role of Congress as the nation's legislature. Can Congress with each of its members dedicated to looking after their own fortunes and those of their constituents be capable of making laws in the interest of the nation as a whole? It has been argued that activities such as advertising and position-taking, which may play well with the folks back home, do little to help make good laws. Particularly when legislation is complicated, one could argue that it is the job of the member of Congress to use their own judgement to lead, rather than follow, their constituents.

There is, however, much material to suggest that the image of members of Congress as 'single-minded seekers of reelection' is an oversimplification. Richard Fenno produced a model where legislators have not one, but three primary goals. ${ }^{6}$ For Fenno, the goal of re-election is joined by two 
others: making good policy and gaining influence within Congress. Naturally, if taking a position on a policy or casting a vote in a certain direction is likely to have a direct effect on their election chances, members will change their behaviour accordingly. However, there will also be many situations where a member's actions will not have such an impact, where an issue has no interest for the voters at home or where there is no guide as to what the opinion of constituents would be. At those times, members are freed from concerning themselves with re-election and can pursue their other goals of making good public policy and improving their own standing within Congress. There is one further question as to what extent members' behaviour is influenced by interest groups who supply much needed funds for election campaigns. This will be dealt with in chapter 8 .

\section{Achieving the goals}

Whatever the specific priorities a member of Congress decides on, they face a number of barriers to achieving their goals. The main obstacle to reaching their ends is the fact they are only one of 100 legislators if in the Senate or one of 435 in the House. For any chosen policy to become law or money to be appropriated for projects, the approval of a majority of both the House of Representatives and Senate is required. Each member's pet projects or key priorities must compete with those of all the other members for their colleagues' support and for time on the Congressional schedule. During the election period, candidates across the country make promises of what they will achieve if elected, however there must be doubt as to exactly how much difference one person can make. This section discusses some of the ways in which legislators try and 
overcome these barriers and successfully achieve the goals of making good public policy and ensuring their eventual reelection.

\section{Policy specialisation}

When the fate of a bill is finally decided on the floor of the House or the Senate, all members are, in theory, equal. All have one vote and are free to cast it in any way they see fit, or not cast it at all if that is what they wish. However, in practice, there is much more to determining what becomes law than the final vote in either chamber. In these areas all members cannot be said to be equal. Hundreds of different policy areas are dealt with by every Congress, with members having the opportunity to debate and vote on issues as diverse as taxation, environmental policy, education, gun law and foreign affairs. It quickly becomes clear to new members that it will not be possible for them to have a significant influence (beyond the right to speak or cast their vote) in all areas of policy. This inevitably leads to members concentrating their efforts on a few carefully chosen issues, a process known as policy specialisation.

Each member of Congress faces many demands on their time and that of their staff. It is simply not possible for them to dedicate their time and resources to gaining expertise in every area of policy. While they will be expected to have an opinion and some knowledge on any given issue that is raised in an election campaign, if a member hopes to become fully active in the legislative process they will usually dedicate their time and resources to a few areas.

The choice of issues will largely be determined by the type of constituency a member of Congress represents. Here the goals of re-election and good public policy can coincide. For 
instance, a Representative whose constituency covers downtown urban New York would gain little benefit from specialising in agricultural policy, however interesting the issue may be. Alternatively, a Senator from a rural state whose primary occupation was farming would hardly be promoting their constituents' interests (or their own re-election chances) if at least one of their key issues was not related to agriculture.

The choice of which issues a member concentrates on may also be influenced by their backgrounds and interests. They may choose to dedicate time to policies in which they have prior experience or expertise, or to issues which they personally feel are important. Especially in the Senate, the choice of speciality can also be influenced by their colleagues choices. There is evidence to show that Senators will try to specialise in different areas to those chosen by the other Senator from their state, so to make sure they have their own territory marked out for the media and voters to see. ${ }^{7}$

At the heart of policy specialisation by members is the committee system of House and Senate, which will be considered in detail in the next chapter. The committees are the engine room of Congress where legislation is researched and formulated. To a large extent the committees are the bodies who decide which legislation will be put to a vote of the House or Senate and which will quietly die. Consequently, for most members, if they are to have any significant influence over an area of policy they must ensure they have a seat on the relevant committee, as it is here that many of the key decisions are made. When first elected to Congress members will supply their party leadership with a wish-list of committees on which they would like to serve. The party leaders will then allocate committee places, with the level of demand for each seat determining how far they can accommodate each legislator's request. 
The allocation of committee seats will go a long way in narrowing the areas in which a member can effectively specialise. While there is nothing to stop a member becoming knowledgeable and speaking out on an issue not under their committees' jurisdiction, the direct influence they can exercise is likely to be limited. Instead, if used to its potential, the committee system will help policy specialisation by giving legislators an arena in which they can both accumulate knowledge and influence policy. Members' influence over their key issue area will rise as they gain a reputation for being an expert in the field and move up the committee hierarchy. When this influence is in a policy area of importance to their constituents, it will also have the effect of aiding their re-election.

\section{Constituency service}

The choice of policy areas to focus on can be viewed as one way of serving constituents and aiding re-election, as can voting in accord with the wishes of the folks back home. There are also ways in which members of Congress can help their constituency more directly.

The most basic of these is constituency case work. Case work entails dealing with the problems or requests of individual constituents. Members receive thousands of letters, emails and telephone calls from their voters every year. Many of these will be communications expressing an opinion on an issue of importance to them or voicing approval or displeasure over the actions of their representative on Capitol Hill. Others will be requesting help for a wide variety of reasons; there may be complaints that a social security or pension cheque has not arrived, a constituent may be having problems with some level of government or a student may request information for a project they are researching. Any member of 
Congress with the intention of being re-elected will ensure that their staff do their utmost to help with each and every problem, even if it is not something which is directly under their control. The gratitude a member will receive from that voter, if their office is seen to be interested or even go out of its way to help, will be greater than any credit which would be received by casting a particular vote or making a rousing speech. Alternatively, if the member's office is seen to be unhelpful or not interested in an individual's problems, the negative effect can outweigh years of good work. The assumption is that a pleased constituent will tell their family and friends about the episode helping to create an image of their member of Congress as someone who cares. A disgruntled voter who feels ignored will also make sure their neighbours know.

Members will also be pro-active in making sure they create an image of a legislator serving their constituency. Regular visits home, appearances at local public, social or sporting events and a high media presence all promote the member as a good 'local' Senator or Representative. Every member maintains at least one office in their constituency (often more than one for Senators from a large state) to allow easy contact with the voters. Building up a good local reputation can create a strong personal following for the member which can ensure re-election. Over the years it has been noticeable that, when polled, voters consistently express a much higher opinion of their own Senators and Representatives than they do of Congress as a whole. This can be partly attributed to the amount of effort members put into serving, or appearing to serve, their constituents. 


\section{Pork barrel}

The most controversial of ways in which members serve their constituents, but perhaps the most effective in terms of building a positive image, is what is know as pork barrel. Pork barrel (so called because the first recorded instance actually involved barrels of pork) is a term used for federally funded projects which a Senator or Representative acquires for their constituency to help with their re-election. These can include projects such as the building of a new hospital, the construction of a new highway bringing jobs and investment, money to help with cleaning a dirty river or assistance to local businesses. Members can be particularly successful at bringing home such benefits to their constituency if they have a place on any committee in charge of distributing such projects or funds.

Critics of Congress argue that much of this spending is wasteful as it directs taxpayers' money to districts with members on the right committee rather than to places which genuinely need such investment. The term 'pork barrel' is, however, a subjective one. What to one person may seem the much needed investment of federal funds into a suitable project in a needy part of the country, to their opponents will be politically motivated pork barrel. Whatever the incentive, members will frequently attempt to claim credit back home for some project or funding their district or state benefited from which is partly due to their intervention. There is no better photo opportunity for a member of Congress than the opening of a new highway, dam, hospital or community project supported by federal funds.

This issue of pork barrel lies at the heart of the debate surrounding the duties and goals of a member of Congress. All 435 House members and 100 Senators play two, often conflicting, roles. They are members of the federal legislature 
which is given the sole responsibility for making national laws by the Constitution, but they are also representatives of specific local areas whether that be a district or state. When federally funded programmes or initiatives are distributed will members be fulfilling their role properly if they fight to benefit the constituents whom they represent or by seeking to serve the national good, even if that means their own voters will not gain? The issue is further muddied by the fact that what constitutes the greatest need is often a matter for debate and interpretation, especially when demand for federal help outstrips the available funds.

\section{Gaining influence within the chamber}

Aside from any personal gratification that may be achieved, the goal of gaining influence within the chamber is largely a means to an end. While being awarded a seat on a committee and becoming active in its deliberations concerning specific policy areas is an important part of a member being able to shape the policies passed by Congress, it is only a first step. Any proposal a member wishes to make may face opposition from other members on the committee or from outside, it will also face stiff competition for a prominent place on both the committee's agenda and the Congressional agenda as a whole. Thousands of proposals are made every Congress by members looking to promote their own or their constituents' interests, but with only two years (the length of a Congress) to complete the journey from bill to law, the majority will fall by the wayside, never making it to a final vote in the House or Senate.

Any member entering Congress for the first time will find there is stiff competition to get their voice heard on any one issue and their priorities considered ahead of the many others 
on the agenda. This is especially true in the House where a legislator is only one voice in a chamber of 435 members. The first job of any member hoping to exert influence within their chamber is to learn the procedures of Congress. It is virtually impossible for a frosh (the term for a first-term legislator) member to personally convince every other legislator necessary to get their bill or proposal considered and then successfully passed through Congress. What they can do is learn the intricacies of the legislative process and which key positions or people hold the most power over such matters as scheduling or are in a position to persuade others. By developing their knowledge of Congress and their relationships with other members, frosh legislators can improve their chances of achieving their goals.

Once members have a few years of service behind them they can start to move into positions of authority either within their committees or party themselves. These topics will be dealt with in more detail in chapters 4 and 5. Suffice to say that posts such as subcommittee or committee chair, or a position of authority within one of the parties bring with them an increased influence over the content and scheduling of legislation. Under the process of seniority members move up the roster of their committees and subcommittees the longer they serve, until reaching the chair or, in the case of the members not belonging to the majority party, the ranking minority position.

Without achieving a formal position of power within Congress, members can begin to assert influence by gaining a reputation of expertise in their chosen areas of policy; many issues are complex and no legislator can hope to become an expert in all fields. When casting a vote for a particular piece of legislation, non-expert members wish to be assured that the 
law they are voting for is a good one, that their vote will not be tied to an unforeseen negative outcome by future opponents. By gaining a reputation of a knowledgeable and trustworthy legislator on a particular issue, a member can potentially increase their influence over the decisions of their colleagues.

\section{Staff support}

To aid their efforts to represent constituents, make good public policy or make their way within Congress, all members are given a great deal of support. Along with the franking privilege and funds to visit their constituency on a regular basis, all members and both parties are given good staff support. Each member establishes their own office and hires the staff to fill it. The budget they are given is set according to the size of their constituency. How much is spent on the Washington office and how much on its constituency equivalent is entirely up to the individual. Currently, there are approximately 24,000 Congressional staff workers serving members, committees and the party leaderships, an increase of some 18,000 since $1960 .{ }^{8}$ The average House member employs 14 staff, the Senate average is 34 .

In addition to personal, committee and party staff, members are supported by a number of legislative agencies. The Congressional Research Service (CRS), the Congressional Budget Office $(\mathrm{CBO})$ and the General Accounting Office (GAO) are all non-partisan offices who will give support to any member looking to research Congressional activity or to write a bill. They are especially helpful in providing expert or technical advice on policy detail or helping staff to frame legislation in the correct legal language. 


\section{Reconciling conflicting goals}

While the theory of the aims and objectives of members of Congress may seem straightforward, the decision-making process for individuals can be a delicate matter of judgement. A member's constituents which can number, for Senators, in the millions, will rarely be of one mind when it comes to how their elected officials should act. Members must make judgements about their constituents' preferences when it comes to expressing opinions, casting votes or choosing which issues to concentrate on. Subjects such as abortion or gun control often split voters evenly but raise strong feelings. When members decide that an issue is of little importance to their constituency and thus leave them free to act according to their conscience, how can they be sure that two years down the line events have not transpired to place the subject at the centre of an opponent's election campaign? Members of Congress must make considered judgements on a wide range of topics. Two examples can help illustrate some of the subtleties involved in Congressional decision making.

\section{The impeachment of President Clinton}

Following allegations of impropriety by President Clinton concerning the so-called 'Whitewater' land deals he, his wife and business partners had made in his home state of Arkansas, an independent council was established to look into the President's behaviour. Failing to find any evidence against the President over Whitewater, the council, Kenneth Starr, began to widen the scope of his investigation. What he discovered was that during a sexual harassment case brought early in his Presidency, Bill Clinton had denied suggestions that he had an affair with White House intern Monica 
Lewinsky. The case actually had little to do with the intern and the denial raised little publicity until Starr revealed that he had evidence that Lewinsky had indeed been involved with the President, a fact which suggested that the President had lied before a Grand Jury. The independent council submitted his report to the House of Representatives in September 1998 accusing the President of obstructing justice.

The US Constitution gives Congress the power to remove the President from office in the event he is proven to have committed 'high crimes and misdemeanours'. First the House of Representatives must impeach the President by majority vote, the Senate will then hold a trial and, if found guilty by a two-thirds majority, the President is removed from office. Following the allegations in Starr's report, the House held hearings, deliberated and finally voted to impeach President Clinton. The Senate began its trial, but, with public opinion swinging firmly behind the President, it failed to achieve even a majority in the vote to remove him from office.

In opinion polls, the public far from approved of the President's action, but a large majority felt that his actions fell well short of the 'high crimes and misdemeanours' needed to impeach. The most common feeling was that this was a man who had seriously erred in his private life, but was still doing a good job as President. Indeed, although nearly 60 per cent of the public believed that the President had lied about his affair with Lewinsky, his job approval ratings rose dramatically during the crisis from 48 per cent before the allegations of infidelity to a high of 70 per cent in February 1999, at the height of the action against him. They were never to fall below 50 per cent again. In polls, 68 per cent felt that Congress should make the debate over social security its main priority with only 23 per cent thinking impeachment as or more 
important. Consistently 60 per cent of the public felt Congress should not remove him from office and, tellingly, 64 per cent believed that most members of Congress had lied to someone about having an extramarital affair. ${ }^{9}$

If members of Congress are so wedded to the views of their constituents when deciding how to act, why did a majority of the House of Representatives defy public opinion and vote to impeach President Clinton? Were they not worried that taking such a position would hurt their standing in the eyes of the voters? As with many actions taken by Congress, there is no simple answer. Many claimed a strong personal feeling that the President had betrayed his office by perjuring himself and lying to the nation. It was, they argued, their duty as a member of Congress to uphold the Constitution and proceed against the President. However, the actual vote on impeachment turned out to be more about party ties than personal conscience. The House divided on the issue largely on party lines with all but five Republicans voting to impeach and all but five Democrats voting to acquit. Party allegiances and Washington politics took precedence over public opinion for three reasons.

Firstly, it seemed unlikely that one member's vote on the issue would have little importance in the 2000 Congressional elections where local issues tend to take centre stage. Except for staunch supporters or opponents of Bill Clinton, would people really change their vote in the Congressional elections over the impeachment of the President? It seemed unlikely and certainly no one should lose their seat over it. Indeed the most likely arena for the decision to have any salience would be the primary elections, where voting with the majority of fellow party members could not be seen as detrimental, although voting against the party could. Secondly, House 
members were in a no-lose situation, if they voted to impeach it would still be the Senate who had to decide whether the President would be removed from office or not. The House action was always one step removed from the final decision on Clinton's fate. Finally, for many Republicans, the opinion polls could not be totally believed; surely, they argued, support could not keep holding up for a President who in their eyes has not only acted immorally, but had perjured himself and lied to the American people. In any event, plunging the Clinton Presidency into further crisis shortly before the end of his term in office would do little harm to the Republican candidates for the presidency and Congress in the year 2000.

By the time the Senate trial came to a close it was clear that the early public support of the President was no freak and, accordingly, the vote went against removing him from office. What opponents of Clinton had trumpeted as a case of perjury and obstruction of justice which threatened the dignity of the White House, the public had clearly seen as a political sex scandal of more tabloid proportions. What the episode can show us is that to perceive of Congressional behaviour as a direct reflection of what constituents want was, in this particular instance, only part of the picture.

\section{Term limits}

For anyone contending the primary objective of any member of Congress is to be consistent re-election at all costs, it may be surprising to find that the Republican Party's 1994 Contract with America contained a commitment to introduce term limits. Under the proposals, after serving two consecutive terms in the Senate or either three or six (members were to be given two options to debate) consecutive terms in the House, members would be barred from running for re-election. The 
idea behind the scheme was to counter the ability of incumbents to be elected time and time again due to the advantages of office, and to replace the long-term professional politician with fresh faces. Currently, eighteen states have similar restrictions on their own legislatures.

When the legislation came to a vote on the House floor, a majority of members voted for the proposal (227:224), but in this instance it was not enough for it to pass. The Supreme Court had ruled earlier in that year that Congressional term limits would require a Constitutional amendment rather than a simple law. According to the Constitution, amendments can only be adopted after gaining a two-thirds majority in both the House of Representatives and the Senate and the approval of two-thirds of the states. In this instance the proposed Constitutional amendment introducing Congressional term limits fell at the first hurdle, failing to achieve the required majority in the House. Forty Republicans joined the majority of Democrats to vote against, with 38 Democrats voting with the majority of Republicans in favour.

To say that the failure of the amendment was a foregone conclusion - that Representatives were not about to vote themselves out of job, even if it was in twelve-years time misses the point that a majority of members appeared to be willing to do just that. We can only speculate as to their true motives. Many may have genuinely believed in the proposals as best for the nation, others, who planned to retire or move on within the next twelve years may have felt freed from protecting their own interests to vote in line with their own beliefs, those of their constituents or with their party leadership. There is also the distinct possibility that, as it became clear that the proposal stood no chance of gaining the twothirds majority needed for it to progress, members were free 
to be seen supporting the idea, all along knowing that their jobs were safe from the consequences of it succeeding.

Of particular interest are those members who during the election campaign, as a matter of principle, pledged to impose their own term limits on themselves if the amendment was not successful. Some of them advocated a much shorter time limit than twelve years and so the strength of their commitment can already be seen. The results were mixed. For instance, Democrat Representative from Massachusetts Martin Meehan, first elected in 1992, pledged to stand down after eight years of service and George Nethercutt from Washington state, a Republican first elected in 1994, promised he would retire after only six years. Once ensconced in Congress both changed their minds and were still in office at the start of the 107th Congress in 2001. Nethercutt explained that 'experience ... taught me that six years may be too short a time to do the job the people ... elected me to do', Meehan argued that campaign finance reform was of such importance that he needed to stay in the House. In contrast to Nethercutt and Meehan, some House members did indeed stick to their own personal term limits. Elizabeth Furse of Oregon (elected in 1992) and Jack Metcalf of Washington state (elected in 1994) both declined to run for re-election after serving three consecutive terms.

What both of these examples illustrate is that, while we can legitimately make assumptions as to the goals and motives of members of Congress, it should not blind us from the fact that every situation is complex and different from next, and the way that each individual will respond to and judge the situation will also vary. 


\section{Summary}

While Congress is becoming a more diverse body, the typical member is still a white male lawyer. Whether this is bad for American democracy is a matter for debate. Whatever the profile of the member, they are likely to have similar goals: to be re-elected, to make good policy and to gain influence within Congress. Which of these goals will be the priority will vary from issue to issue and will be a delicate matter for each member's judgement. Attention to the needs of constituents will always be important. To achieve any of these goals, members will need to specialise in certain areas of policy in order to get their voice heard and their proposals passed. At the heart of this is the committee system.

\section{Notes}

1 Population figures from the 2000 Census, Office of the Census, Washington DC (www.census.gov).

2 Congressional Quarterly Weekly Report.

3 Congressional Research Service, Membership of the 107th Congress: A Profile, order code: RS20760, p. 3.

4 D. R. Mayhew, Congress: The Electoral Connection (New Haven: Yale University Press, 1974).

5 Ibid, pp. 16-17.

6 R. F. Fenno Jr. Congressmen in Committees (Boston: Little, Brown, 1973).

7 W. Schiller, Partners and Rivals (Princeton: Princeton University Press, 2000).

8 See N. Ornstein, T. Mann and M. Malbin (eds.), Vital Statistics on Congress, 1999-2000 (Washington DC: American Enterprise Institute, 1999).

9 Figure from Rasmussen Research; supplied at www.portraitofamerica. com. 